\title{
Vlog-Based Assignment: A Mean of Improving PGSD Students' Communicative Skill in Presenting Science Subject
}

\author{
Dian Firdiani ${ }^{1}$,Rahmat Rahmat ${ }^{2}$, Ita Sarmita Samad ${ }^{3}$ \\ ${ }^{1}$ (Primary School Teacher Education Department, Universitas Muhammadiyah Enrekang, Indonesia) \\ ${ }^{2}$ (Primary School Teacher Education Department, Universitas Muhammadiyah Enrekang, Indonesia) \\ ${ }^{3}$ (English Department, Universitas Muhammadiyah Enrekang, Indonesia) \\ * Corresponding Author. E-mail: ${ }^{1}$ itaneverendita@gmail.com
}

Receive: $12 / 09 / 2020$

Accepted: 01/10/2020

Published: 03/10/2020

\begin{abstract}
Communicative skill is important to be mastered by primary teacher candidates. The skill is required to create conducive teaching and learning process. Meanwhile, the fact shows that the students of primary school teacher (PGSD) at STKIP Muhammadiyah Enrekang have low communicative skill. Involving technology in learning is considered to be able to assist the teacher to hone the students' communicative skill. Vlog or video blog which is technology-based can be a way to overcome the issue. The present study aims at investigating whether the use of vlog-based assignment can improve the students' communicative skill and affect their selfconfidence. Quantitative research method with quasi-experimental research design is used to complete this research. The instruments used to collect data are questionnaire and test which is arranged based on the communicative skill indicators and validated by an expert. In conclusion, the use of vlog-based assignment gives positive impact to the level of self-confidence of the students and thus enhance the students' communicative skill as well.
\end{abstract}

Keywords: Communicative skill; Vlog; Youtube, Science

\section{Introduction}

Communicative skill is one of the important skills that have to be mastered by teacher candidates of primary school. It is a capacity to effectively and efficiently transmit the knowledge to the students. That is why the teacher candidates must hone this skill in order tocreate an effective teaching and learning process and thus the teaching goals can be achieved.

This present study is motivated by the fact shows that most of the students of primary school teacher education (PGSD) of STKIP Muhammadiyah Enrekang tend to have low communicative skill. It was confirmed when the students did group or individual presentation in the class through education learning with Hasnidar, et.all., (2020). Theyseem rigid in conveying their material especially for science. Hence, the learning activity did not run well. Furthermore, the students rarely utilize technology in arranging the learning material in the teaching practicum activity. In contrast, revolutionary era 4.0 calls for creating innovative and creative forms of learning based on technology.

In order to overcome those issues, there must be a way that is used to create the effective, meaningful, interesting, and challenging learning activity and the development of vocational with Djafar (2020). One of the ways is by applying technology. This is in line with Philips (2014) stated that students are highly motivated to learn through technology since it offers active participation, cooperative teamwork, and helps studentswith wider sources with Saharuddin (2020). Vlog or Video Blogging which is technology-based is considered to attract the students' interest in learning. At least, there are 3 reasons for it. 
Jurnal Edumaspul, 4 (2), Year 2020 - 2

((Dian Firdiani,Rahmat Rahmat, Ita Sarmita Samad)

The first, vlog is familiar to the students' daily lifenowadays. The second, vlog tends to easy to make since every students has smartphone. Thethird, the students tend to addicted in gadget.

Based on the background above, the researcher intends to conduct a study on the use of vlog. It aims at investigating 2 research questions. 1) Can the use of vlog-based assignment affect the students' selfconfidence? 2) Can the use of vlog-based assignment enhance the students' communicative skill in conveying the science subject? Finally, it is regarded urgent to undertake this research since it is expected to

\section{Method}

The research used quantitative research method. Especially, it used quasi-experimental research design. The participants were the second semester students of PGSD STKIP Muhammadiyah Enrekang in academic year $2019 / 2020$. The participants consist of 40 students which is 20 students of experimental class (PGSD IV A) and 20 students in control class (PGSD IV B). The students in the experimental class will be treated through the application of vlog based assignment while the students in the control class will be treated through the conventional teaching technique (group presentation). give valuable inputfor the students, the lecturer, the future researcher, and also for the educational system especiallyin Indonesia. For the students, it is expected that they communicative skill can be enhanced astheir provision to be a professional primary teacher. For the lecturer, it is expected that they canupdate their way of teaching as a mean of assisting them to reach the teaching goal. For thefuture researcher, it is expected that they can use the result of this research as precious referencefor the related study. The last is it is expected it can give positive contribution for the quality ofeducational system in this country.

The instruments used to collect data were questionnaire and test. This instrument is made based on the indicators of communicative skill. After that, the instrument is validated by the expert. The data collected from the instruments were analyzed using SPSS 25.

\section{Result and Conclusion}

1. The Effectiveness of Vlog-Based Assignment towards the Students' Self Confidence

The data obtained from questionnaire is used to analyze the influence of using vlog-based assignment towards the students' selfconfidence. The following table is the result.

\begin{tabular}{lcccc}
\hline \multicolumn{1}{c}{ Data } & \multicolumn{2}{c}{ Experimental Class } & \multicolumn{2}{c}{ Control Class } \\
\hline N & Pretest & Posttest & Pretest & Posttest \\
\hline Min & 20 & 20 & 20 & 20 \\
\hline Max & 56 & 66 & 47 & 56 \\
\hline Mean & 80 & 92 & 95 & 96 \\
\hline
\end{tabular}

Table. 1 Descriptive Analysis of questionnaire data

The data displayed on the table 1 indicates that the mean score of posttest in the experimental class is higher than the mean score of posttest in the control class. It confirms that there is a difference between the students' self confidence in the treatment class and those who are in the experimental class after giving the treatment.
Thence, in order to assure whether the hypothesis is accepted or not, the researcher analyzed the $T$ test. Still, the researcher analyzed the inferential data (perquisite test) beforehand as a mean of testing whether the data is qualified or not. The result is shown in the table 3 and table 4 
Jurnal Edumaspul, 4 (2), Year 2020 - 3

(Dian Firdiani,Rahmat Rahmat, Ita Sarmita Samad)

\begin{tabular}{lr|r|r|r|r|r} 
& \multicolumn{3}{c}{ Kolmogorov-Smirnova } & \multicolumn{3}{c}{ Shapiro-Willk } \\
& Statistic & \multicolumn{1}{c}{ df } & \multicolumn{1}{c}{ Sig. } & Statistic & \multicolumn{1}{c}{ df } & \multicolumn{1}{c}{ Sig. } \\
\hline KELAS EKSPERIMEN & .132 & 20 & $.200^{*}$ & .976 & 20 & .878 \\
\hline KELAS KONTROL & .175 & 20 & .110 & .923 & 20 & .112 \\
\hline
\end{tabular}

Table. 2 Tests of Normality

\begin{tabular}{|c|c|c|c|c|c|}
\hline & & Levene Statistic & df1 & df2 & Sig. \\
\hline \multirow[t]{4}{*}{ KELAS EKSPERIMEN } & Based on Mean & 9.604 & 4 & 6 & .009 \\
\hline & Based on Median & 3.495 & 4 & 6 & .084 \\
\hline & $\begin{array}{l}\text { Based on Median and with } \\
\text { adjusted df }\end{array}$ & 3.495 & 4 & 2.000 & .235 \\
\hline & Based on trimmed mean & 9.006 & 4 & 6 & .010 \\
\hline
\end{tabular}

Table 3. Test of Homogeneity of Variances

Table 2 shows that sig score found from the data is higher than sig $\alpha(5 \% / 0,05)$ or $0,200>$ 0,05 . It implies that all of the data is normally distributed. Likewise, the data displayed on the table 3 shows that the sig score based on mean is smaller than sig $\alpha(0,009<0,05)$ and the sig score based on median is higher than sig $\alpha$
$(0,84>0,05)$. Thus, it can be stated that the posttest data in the experimental class is homogeny with the posttest data in the control class. In such a way, the researcher can continue to analyze the $\mathrm{T}$ test due to the perquisite test is qualified.

\begin{tabular}{lllll}
\hline NO NILAI & Tcounted & Trable & Sig Level & Is \\
\hline 1 & Equal variances assumed & 4,401 & 1,688 & 000 \\
\hline
\end{tabular}

Table 4. Independent Samples T test

2. The data from table 4 shows that t counted $>\mathrm{t}$ table $(4,401>1,688)$. Thus, it can be concluded that $\mathrm{H} 1$ is accepted while $\mathrm{HO}$ is rejected. In other words, there is a significance difference between the students' self-confidence in the experimental class and the students in the control class.

Afterward, the students' distribution score of self-confidence can be grouped in 5 categories.
They are very high, high, medium, low and very low. The students' score are categorized based on the interval class. The maximum score that the students can obtain is $122(5 \times 22)$ while the minimum score is $22(1 \times 22)$. Both of the score is used to determine the interval class. Thus, the interval class found is 20 and is arranged into 5 categories which are described in the following table.

\begin{tabular}{|l|l|c|c|c|c|}
\hline \multirow{2}{*}{ Category } & \multirow{2}{*}{ Score Range } & \multicolumn{4}{|c|}{ Subject Total } \\
\cline { 3 - 6 } & & Experimental & Percentage & Control Class & \multirow{2}{*}{ Percentage } \\
\hline Very High & $102-122$ & - & - & - & - \\
\hline High & $82-101$ & 6 & $30 \%$ & 1 & $5 \%$ \\
\hline Medium & $62-81$ & 14 & $70 \%$ & 16 & $80 \%$ \\
\hline Low & $42-61$ & - & - & 3 & $15 \%$ \\
\hline Very Low & $22-41$ & - & - & - & - \\
\hline
\end{tabular}

Table 5. Distribution Score of Self-Confidence 
Jurnal Edumaspul, 4 (2), Year 2020 - 4

((Dian Firdiani,Rahmat Rahmat, Ita Sarmita Samad)

3. Table 5 shows that there are 6 students in the experimental class have high selfconfidence while only 1 students in the control class who has high self-confidence. Then, there are 14 students or $70 \%$ of the students in the experimental class have medium self-confidence while there are 16 students in the control class are in this level of self-confidence. For the low level of self-confidence, there is none of the students in the experimental class get this level meanwhile there are 3 or $15 \%$ of the students in the control class who are in this level of self-confidence.
4. Thus, it can be concluded that the treatment given (vlog-based assignment) can give a positive effect to the students' level of self-confidence. This is in line with Sari (2017) stated that the students became more inspired and confident in their class to communicate after doing the task of making video-blog. Their selfconfidence are gradually improved. Additionally, Izatussariroh (2019) stated that since the students nowadays are familiar with technology and social media, the vlog project also can increase the students'self-confidence.

5. The Effectiveness of Vlog-Based Assignment towards the Students' Communicative Skill

The instruments used to collect the data of the students' communicative skill are pre-test and posttest. They can be seen in the following table.

\begin{tabular}{lcccc}
\hline \multicolumn{1}{c}{ Data } & \multicolumn{2}{c}{ Experimental Class } & \multicolumn{2}{c}{ Control Class } \\
\hline & Pretest & Posttest & Pretest & Posttest \\
\hline N & 20 & 20 & 20 & 20 \\
\hline Min & 55 & 62 & 50 & 50 \\
\hline Max & 70 & 87 & 73 & 75 \\
\hline Mean & 64.10 & 72.45 & 62.60 & 64.35 \\
\hline
\end{tabular}

6. Table 6. The Result of Pretest and Posttest

7. Table 6 shows that the mean score of posttest in the experimental class is higher than the mean score of posttest in the control class. It means that there is a difference of the communicative skill between the students' in the experimental

Furthermore, the researcher analyzed the inferential data (Prerequisite Test) of the students' score before analyzing the T-test. The inferential data consist of 2 kinds. They are test of normality and test of homogeneity of variances. The result can be seen as follows. class and control class after giving the treatment.

\begin{tabular}{|c|c|c|c|c|c|c|}
\hline \multirow[t]{2}{*}{ 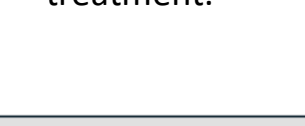 } & \multicolumn{3}{|c|}{ Kolmogorov-Smirnova } & \multicolumn{3}{|c|}{ Shapiro-Wilk } \\
\hline & Statistic & $\mathrm{df}$ & Sig. & Statistic & $\mathrm{df}$ & Sig. \\
\hline CONTROL CLASS & .158 & 20 & $.200^{*}$ & .957 & 20 & .481 \\
\hline $\begin{array}{l}\text { EXPERIMENTAL } \\
\text { CLASS }\end{array}$ & .158 & 20 & $.200^{*}$ & .922 & 20 & .110 \\
\hline
\end{tabular}

8. Table 7. Tests of Normality

Based on the data of table 7 , it can be confirmed that all of the variable data is normally distributed. It is because the score of sig is higher than sig $\alpha(5 \% / 0,05)$ or $0,200>$ 0,05 . 
Jurnal Edumaspul, 4 (2), Year 2020 - 5

(Dian Firdiani,Rahmat Rahmat, Ita Sarmita Samad)

\begin{tabular}{|c|c|c|c|c|c|}
\hline & & Levene Statistic & df1 & df2 & Sig. \\
\hline \multirow[t]{4}{*}{ Experimental Class } & Based on Mean & 3.643 & 4 & 11 & .040 \\
\hline & Based on Median & 1.827 & 4 & 11 & .194 \\
\hline & $\begin{array}{l}\text { Based on Median and with } \\
\text { adjusted df }\end{array}$ & 1.827 & 4 & 5.953 & .243 \\
\hline & Based on trimmed mean & 3.713 & 4 & 11 & 038 \\
\hline
\end{tabular}

9. Table 8. Test of Homogeneity of Variances Table 8 shows that the posttest data of control class is homogeny with the posttest data of experimental class. It can be confirmed by the score of sig based on mean score is smaller than sig $\alpha(0,04<0,05)$ and the score of sig based on median is higher than the sig $\alpha(0,194$

Since the result of inferential data (Prerequisite Test) analysis shows that the data is normally distributed and homogeny thus it is qualified to analyze the T-test. The result is displayed in the following table. $>0,05$ ).

\begin{tabular}{|l|l|l|l|l|}
\hline NO & NILAY & thitung & trabel & Taxar Sig \\
\hline 1 & Equal variances assumed & 4,233 & 1,685 & O,OOO \\
\hline
\end{tabular}

Table 9. Independent Samples $T$ test

The table shows that $\mathrm{t}$ counting is higher that $\mathrm{t}$ table $(4,233>1,685)$. It means that $\mathrm{H} 1$ is accepted while $\mathrm{HO}$ is rejected. It indicates that there is a significance difference between the students in the control class and experimental class in terms of the students' communicative skill after giving treatment. In other words, the students who were given treatment with vlogbased assignment had better communicative skill than they who were not.

The fact is supported by Ma'mur (2013) who stated that the learning process must be active, creative, effective and fun. Hence, the teacher has to be competent in choosing teaching media that can stimulate the students' activeness and creativeness. In this case, vlog can be one of such media. References

[1] Baran, E. (2007). The promises of video blogging in education. The Annual Convention

the Association for Educational Communications and Technology. Retrieved from

http://uwispace.sta.uwi.edu/dspace/handl e/2139/21612

[2] Chatab, N. (2007). Profil budaya organisasi. Bandung: Alfabeta.

[3] Djafar, S., Nadar, N., Arwan, A., \& Elihami, E. (2019, October). Increasing the Mathematics Learning through the Development of Vocational Mathematics Modules of STKIP Muhammadiyah Enrekang. In International Conference on
Furthermore, Priana (2017) explained that in terms of delivering material as well as doing presentations, the creativity of either the students or the teacher who develop Vlog as media requires learning to be more interactive and thus attract the students. Consequently, the students' communicative skill can be improved as well.

\section{Conclusion}

In conclusion, the research questions can be answered. The first is the use of vlog-based assignment can affect the students' selfconfidence. This gives positive impact to the level of self-confidence of the students. The second is the use of vlog-based assignment can enhance the students' communicative skill

Natural and Social Sciences (ICONSS) Proceeding Series (pp. 246-251).

[4] Efendi, A., \& Elihami, E. (2020). GUIDELINING FOR LEARNING TO OPTIMIZING LEARNING ACHIEVEMENT. Jurnal edukasi nonformal, 1(1), 56-62.

[5] Eskarya, H., \& Elihami, E. (2020). THE INSTITUTIONAL ROLE OF FARMER GROUPS TO DEVELOP THE PRODUCTION OF COCOA.JURNAL EDUKASI NONFORMAL, 1(1), 81-87.

[6] Fidan, M. \& Debbag. M. (2018). The usage of video blog (vlog) in the "school experience"course: The opinions of the pre-service teachers. Journal of Education and Future year, 13161-177. 
Jurnal Edumaspul, 4 (2), Year 2020 - 6

((Dian Firdiani,Rahmat Rahmat, Ita Sarmita Samad)

[7] Gonzales, K. (2018). Communication skills: Definition and examples Retrieved from https://study.com/academy/lesson/comm unication-skills-definition-examples.html

[8] Hasnidar, H., \& Elihami, E. (2019). The management Model of National Character Education for Early Childhood Education through based on Democracy. Edumaspul: Jurnal Pendidikan, 3(1), 15-19.

[9] Haslinda, H., \& Elihami, E. (2020). DEVELOPING OF CHILDRENS PARK PROGRAM 'SITTI KHADIJAH'IN ENREKANG DISTRICT. JURNAL EDUKASI NONFORMAL, 1(1), 41-47.

[10] Iqbal, M. (2019). Pengembangan video blog (vlog) channel youtube berbasis stem sebagai media alternative pembelajaran online (Bachelor theses, Universitas Islam Negeri Raden Intan Lampung). Retrieved from

repository.radenintan.ac.id/7572/1/SKRIP SI.pdf

[11] Ismail, I., Elihami, E., \& Mustakim, M. (2019). Students' Perceptions of the Benefits of Mobile Polling Technology in Teaching and Learning in College: Implications of Students' Participation and academic Performance. Jurnal Pendidikan Progresif, 9(1), 89-104.

[12] Khalik, M. F., Asbar, A., \& Elihami, E. (2020). THE QUALITY OF HUMAN RESOURCE IN ENREKANG DISTRICT. JURNAL EDUKASI NONFORMAL, 1(1), 63-71.

[13] Latifah, N. \& Vebrianto, R. (2017). Pengembangan media pembelajaran berbasis multimedia blog untuk matapelajaran Sains. Seminar Nasional Teknologi Informasi, Komunikasi dan Industri (SNTIKI) 9 (pp. 690-695). Pekanbaru, UIN Sulatan Syarif Kasim Riau. Retrieved from http://ejournal.uinsuska.ac.id/index.php/SNTIKI/article/dow nload/3160/2195.

[14] Lestari, N. (2019). Improving the speaking skill by vlog (video blog) as learning media : The EFL students' perspective. International Journal of Academic Research in Business and

Social Sciences, 9(1), 915-925. Doi: 10.6007/IJARBSS/v9-i1/5490.

[15] Maulidah, I. (2017). Vlog: The mean to improve students' speaking ability.
Advances in

Social Sciences, Education and Humanities Research. Doi: https://doi.org/10.2991/iconelt17.2018.3

[16] Phillips, G. D. (2014). An investigation into the use of technology enhanced learning into curriculum delivery in the educational distict of Tobago. Jamaika: The University of

the West Indies.

[17] Safitri, N. \& Khoiriyah I. (2017). Students' perception on the use of English vlog (video

blog) to enhance speaking skill. ASEAN Academic Society International Confrence. Retrieved

from http://aasic.org/proc/aasic/article/view/ 298

[18] Saharuddin, A., Wijaya, T., Elihami, E., \& Ibrahim, I. (2020). LITERATION OF EDUCATION AND INNOVATION BUSINESS ENGINEERING TECHNOLOGY.JURNAL EDUKASI NONFORMAL, 1(1), 48-55.

[19] Sari, P. (2017). Using vlog in the youtube chanel as a means to improve students motivation

and confidence to speak English in intermediate 1 level of LB-LIA Jambi. International

Journal of English Language and Teaching, 1(1), 38-44. Doi: https://doi.org/10.22437/ijolte.v1i1.4596

[20] Susanti, E. D. (2019). Project based learning: Pemanfaatan vlog dalam pembelajaran untuk generasi pro gadget. Sejarah dan Budaya: Jurnal Sejarah, Budaya, dan pengajarannya, 13(1), 85-96. doi: um020v13i12019p84.

[21] Watanabe, L. (2017, February 22). 8 Methods for effectively improving students communication skill (Web log post). Retrieved from https://www.wabisabilearning.com/blog/ 8-methods-improving-studentcommunication-skills

[22] Wulandari, M. (2019). Improving EFL learners' speaking proficiency through instagram vlog. LLT Journal: A Journal on Language and Language teaching, 22(1), 111-125. Doi: doi.org/10.24071/llt.2019.220111 